
Not for reproduction, distribution or commercial use.

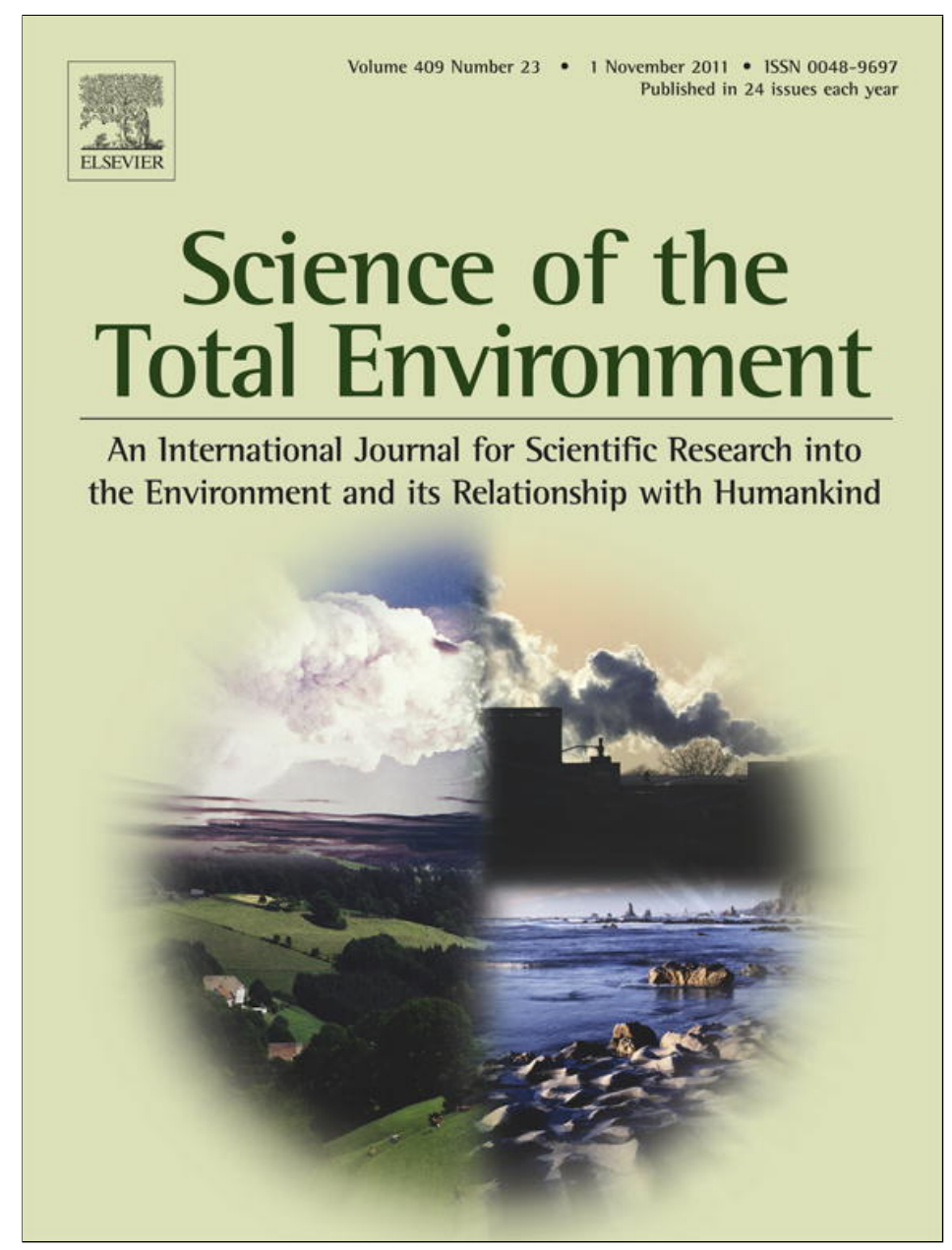

This article appeared in a journal published by Elsevier. The attached copy is furnished to the author for internal non-commercial research and education use, including for instruction at the authors institution and sharing with colleagues.

Other uses, including reproduction and distribution, or selling or licensing copies, or posting to personal, institutional or third party websites are prohibited.

In most cases authors are permitted to post their version of the article (e.g. in Word or Tex form) to their personal website or institutional repository. Authors requiring further information regarding Elsevier's archiving and manuscript policies are encouraged to visit:

http://www.elsevier.com/copyright 


\title{
Long-range effect of cyanide on mercury methylation in a gold mining area in southern Ecuador
}

\author{
Jean Remy Davée Guimaraes ${ }^{\text {a,* }}$, Oscar Betancourt ${ }^{\text {b }}$, Marcio Rodrigues Miranda ${ }^{\text {a }}$, Ramiro Barriga ${ }^{\text {c, }}$ \\ Edwin Cueva ${ }^{\mathrm{b}}$, Sebastián Betancourt ${ }^{\mathrm{b}}$ \\ a Laboratorio de Traçadores, IBCCF/UFRJ, CCS, Bloco G, Av. Carlos Chagas Filho s/n, CEP 21941-902 Rio de Janeiro, RJ, Brazil \\ ${ }^{\mathrm{b}}$ Health, Environment and Development Foundation, FUNSAD, Ecuador \\ c National Polytechnic School, Ecuador
}

\section{A R T I C L E I N F O}

\section{Article history:}

Received 16 April 2011

Received in revised form 11 August 2011

Accepted 13 August 2011

Available online 10 September 2011

\section{Keywords:}

Cyanidation

Puyango river

Water

Sediment

Radiotracers

\begin{abstract}
A B S T R A C T
Small-scale gold mining in Portovelo-Zaruma, Southern Equador, performed by mercury amalgamation and cyanidation, yields 9-10 t of gold/annum, resulting in annual releases of around $0.65 \mathrm{t}$ of inorganic mercury and $6000 \mathrm{t}$ of sodium cyanide in the local river system. The release of sediments, cyanide, mercury, and other metals present in the ore such as lead, manganese and arsenic significantly reduces biodiversity downstream the processing plants and enriches metals in bottom sediments and biota. However, methylmercury concentrations in sediments downstream the mining area were recently found to be one order of magnitude lower than upstream or in small tributaries. In this study we investigated cyanide, bacterial activity in water and sediment and mercury methylation potentials in sediments along the Puyango river watershed, measured respectively by in-situ spectrophotometry and incubation with ${ }^{3} \mathrm{H}$-leucine and ${ }^{203} \mathrm{Hg}^{2+}$.

Free cyanide was undetectable $\left(<1 \mu \mathrm{g} \cdot \mathrm{L}^{-1}\right)$ upstream mining activities, reached $280 \mu \mathrm{g} \cdot \mathrm{L}^{-1} \mathrm{a}$ few $\mathrm{km}$ downstream the processing plants area and was still detectable about $100 \mathrm{~km}$ downstream. At stations with detectable free cyanide in unfiltered water, $50 \%$ of it was dissolved and $50 \%$ associated to suspended particles. Bacterial activity and mercury methylation in sediment showed a similar spatial pattern, inverse to the one found for free cyanide in water, i.e. with significant values in pristine upstream sampling points (respectively 6.4 to $22 \mu \mathrm{gC} \cdot \mathrm{mg}$ wet weight ${ }^{-1} \cdot \mathrm{h}^{-1}$ and 1.2 to $19 \%$ of total ${ }^{203} \mathrm{Hg} \cdot \mathrm{g}$ dry weight ${ }^{-1} \cdot$ day $^{-1}$ ) and undetectable downstream the processing plants, returning to upstream values only in the most distant downstream stations. The data suggest that free cyanide oxidation was slower than would be expected from the high water turbulence, resulting in a long-range inhibition of bacterial activity and hence mercury methylation. The important mercury fluxes resultant from mining activities raise concerns about its biomethylation in coastal areas where many mangrove areas have been converted to shrimp farming.

(C) 2011 Elsevier B.V. All rights reserved.
\end{abstract}

\section{Introduction}

The Puyango River basin is situated in South Western Ecuador, near the border with Peru and has been a site of gold and silver mining since pre-colonial times, leading to the present name of the province, El Oro. In the Portovelo-Zaruma region, upper Puyango basin, larger scale mining by foreign companies produced $1000 \mathrm{t}$ of $\mathrm{Au}, 500 \mathrm{t}$ of $\mathrm{Ag}$ and $1500 \mathrm{t}$ of Cu during the first half of the 20th century (Astudillo, 2007). In the 1980s, an economic crisis combined with a sharp increase in gold prices led to the invasion of abandoned mines, resulting in a boom of smallscale mining. Today, over 110 small riverside processing plants operate in the region, extracting approximately 9-10 $\mathrm{t}$ of gold per annum by a combination of amalgamation with $\mathrm{Hg}$ and cyanide leaching from ore coming from over 400 mines. This combination of extraction processes

\footnotetext{
* Corresponding author. Tel.: + 552125626651.

E-mail address: jeanrdg@biof.ufrj.br (J.R.D. Guimaraes).
}

is not exclusive to Ecuador and is used in other developing countries for the same reason, namely the low gold recovery when using $\mathrm{Hg}$ amalgamation alone. Velasquez-Lopez et al. $(2010,2011)$ described in close detail the extraction processes used by the miners from Portovelo-Zaruma and, more important, the inventory of the resultant $\mathrm{Hg}$ and cyanide emissions in each step of the process. Besides gold, the sulfur-rich polymetallic ore they process contains high concentrations of $\mathrm{Mn}, \mathrm{Cd}, \mathrm{Pb}, \mathrm{As}, \mathrm{Cu}$ and $\mathrm{Zn}$ and inadequate management of mine tailings results in the discharge of toxic cyanide effluents and of sediments highly enriched with $\mathrm{Hg}$ and other metals, and the signature of mining activity in sediments and suspended particles is detectable far downstream (Tarras-Wahlberg et al., 2001; Betancourt et al., 2005). In the 2000 dry season $\mathrm{Hg}$ in suspended sediments $100 \mathrm{~km}$ downstream the processing plants was $\sim 400 \mathrm{ng} \cdot \mathrm{g}^{-1}$. dry weight and it increased by one order of magnitude in the wet season, while for lead the concentrations were 250 and $2600 \mu \mathrm{g} \cdot \mathrm{g}^{-1}$ in the dry and wet season respectively. 
The cyanidation plants operate in a hilly region and due to the scarcity of flat areas the mining facilities and cyanidation plants are built directly on the river banks and as a consequence cyanidation plants respond for $\pm 80 \%$ of the sediment slurry laden by mining activities to the river (Prodeminca, 1998). In May 2011, over 110 cyanidation plants were operating in the region, releasing estimated $880.000 \mathrm{t} / \mathrm{a}$ of tailings into the river (Veiga, 2011). The Puyango river flows into the Tumbes River that reaches the Pacific Ocean, transporting mining-derived metals to the coastal areas, affecting mangroves and large shrimp farms. Studies in the 70s and 80s have estimated that about $289 \mathrm{~kg}$ of $\mathrm{Hg}$ was annually discharged into the Calera River in Portovelo-Zaruma (Prodeminca, 1998) and recently Velasquez-Lopez et al. (2010) estimated an annual discharge of $430 \mathrm{~kg}$ of $\mathrm{Hg}$.

Betancourt et al. (2005) studied the impact of mining on environment and human health along the Puyango river basin, documenting the occupational exposure to $\mathrm{Pb}$ and $\mathrm{Hg}$ in the upper basin, where the intake of fish and river water are low, and the high exposure to lead in the semi-arid lower basin, where the population relies heavily on the river for fish and water supply. They found very low suspended particle loads upstream the mining area, ranging from 1.6 to $3.0 \mathrm{mg} \cdot \mathrm{L}^{-1}$ depending on the season, while near the processing plants, levels ranged $132-328 \mathrm{mg} \cdot \mathrm{L}^{-1}$, and similar profiles were found for metals in river sediments, with maximum mercury concentrations of $0.061 \mu \mathrm{g} \cdot \mathrm{g}^{-1}$ upstream mining activities and $0.730 \mu \mathrm{g} \cdot \mathrm{g}^{-1}$ downstream.

However, Roulet et al., 2006 found that methylmercury was at least one order of magnitude lower in sediments downstream the mining area when compared to levels upstream or in small tributaries unaffected by mining activities, both as absolute concentrations or as \% of total mercury and raised the hypothesis that gold mining could be reducing methylmercury. Mercury is converted from Hg (II) to methylmercury by microbiological activity and such low methylmercury concentrations and percentages suggest a very low availability of mercury, possibly due to its binding to sulfur, abundant in the processed ore and hence in the mining effluents, and/or a strong inhibition of microbiological activity due to the very high cyanide concentrations in these effluents. For the present study we returned to the region in 2009 to test the second hypothesis, measuring cyanide and bacterial activity in water along the Puyango river basin, as well as bacterial activity and mercury net methylation potentials in bottom sediments, in three reference stations upstream the mining area and four stations downstream.

\section{Materials and methods}

\subsection{Study area and sampling sites}

The Puyango River crosses southern Ecuador from NE to SW from the Andes' western foothills to the border with Peru, where it changes its name to Tumbes River, before finally reaching the Pacific Ocean (Fig. 1).

The Upper Basin of the Puyango includes the Zaruma and Portovelo mining and urban centers (stations 4 ) and the reference sampling stations upstream (stations 1 to 3 ): it is a temperate humid region. The Middle Basin includes Puyango Viejo and Marcabelí and it is a sub-tropical humid region, while the Lower Basin (GramadalLas Vegas and Chaguarhuaycu) is a tropical semi-arid region. The Upper Basin has around 42,000 inhabitants while the middle and lower parts of the Basin are scarcely populated. The river is an important source of fish and drinking water for communities living in the semi-arid Lower Basin while the towns of Zaruma and Portovelo in the upper basin draw their drinking water from small Puyango tributaries. Agriculture and cattle are the predominant economic activities in the Lower and Middle Basin, aside from gold mining. The reference stations 1 to 3 are almost pristine and range 1550 to $1820 \mathrm{~m}$ in altitude with little or no agriculture upstream. The waters carry very little suspended particulate matter and support a varied fauna of birds, macroinvertebrates and fish. In contrast, stations 4 and 5 are under the direct influence of untreated urban sewage and of mining effluents, showing very high levels of particulate matter and cyanide, $\mathrm{Pb}$, $\mathrm{Cd}, \mathrm{Mn}$ and $\mathrm{Hg}$ among other metals, leading to a severe reduction in the density and diversity of the aquatic fauna. The latter parameters

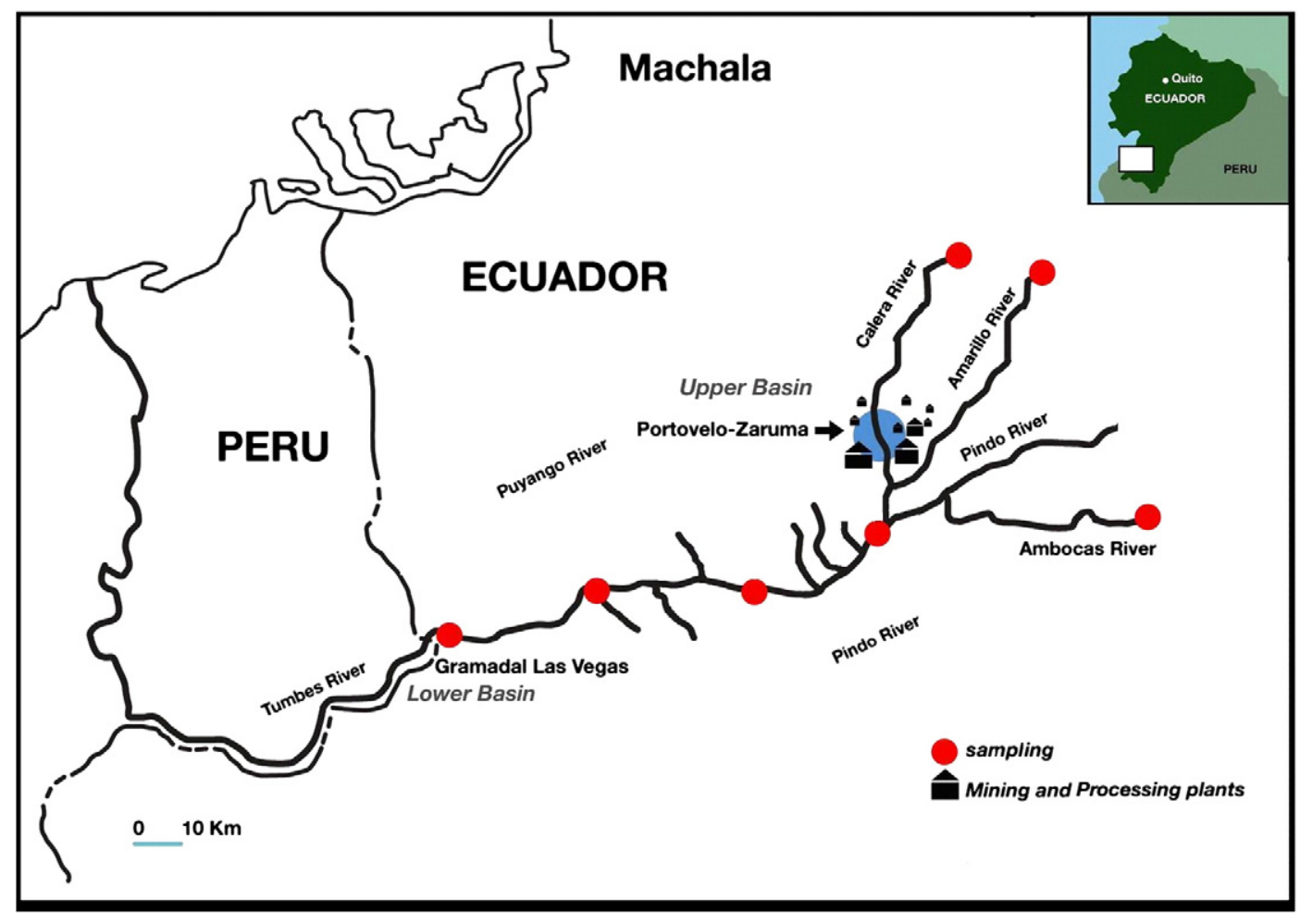

Fig. 1. Map of the study area and sampling stations, Puyango river basin, Ecuador. 
increase only in farthest downstream station 7 , at $155 \mathrm{~m}$ of altitude on the semi-arid coastal plain. Our sampling stations covered a $145 \mathrm{~km}$ stretch of the Puyango River basin. Inventories of benthic macro-invertebrate river fauna at background sites by TarrasWahlberg et al. (2001) showed the existence of 17 taxa in the upper Calera, and 13-23 taxa in uncontaminated stretches of the Pindo river but even as far as $160 \mathrm{~km}$ downstream the mining area only 5 taxa were found.

Fig. 2 shows the altimetric profile of the Puyango basin, illustrating its high turbulence - and therefore turbulence - in the higher and middle basin and Fig. 3 shows the typical dry season pattern for suspended particulate matter load in water across the study region, as measured during the dry season of year 2000 by Betancourt et al., 2005. The different measurements described herein were made in the 2009 dry season.

\subsection{In-situ measurement of cyanide in water}

Free cyanide was measured in-situ, immediately after sampling, on a Hach field spectrophotometer model DR 2010 using the manufacturer reagent kit (Pyridene-Pyrazolone method, Hach reference 8027). This method is based on the chlorination of cyanide and the subsequent reaction of the product with a mixed solution of pyridinepyrazolone to form a stable complex dye. The method can be used to quantify total cyanide if samples are submitted to a previous distillation step. This was not possible in our field conditions, therefore the presented data refer to free and/or simple cyanides only.

Measurements were made both on unfiltered and on $0.22 \mu \mathrm{m}$ filtered water samples. The detection limit of the method was $1 \mu \mathrm{g} \cdot \mathrm{L}^{-1}$. Measurements of successive aliquots of the same sample of unfiltered or filtered water deviated by less than $2 \%$. Free cyanide concentrations in the first two stations downstream the processing plants region were so high that a 20 to 50 fold sample dilution with distilled water was required to fall within the measuring range.

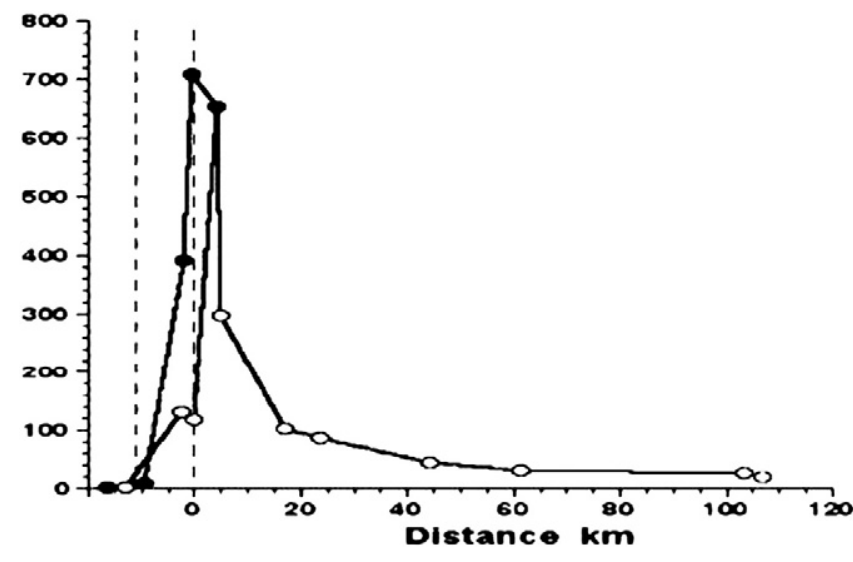

Fig. 3. Variation of the suspended particle load $\left(\mathrm{mg} \cdot \mathrm{L}^{-1}\right)$ along the Puyango river study area, November 2000.

From Betancourt et al. (2005).

\subsection{Bacterioplankton activity essays}

The procedure for bacterial activity measurements was based on the method described by Kirchman et al. (1985), modified by Miranda et al. (2007). It consists of measuring the incorporation of radiolabeled leucine into bacterial protein over time (Kirchman et al., 1985). Unfiltered water samples of $1 \mathrm{~mL}$ were incubated in the dark for $1 \mathrm{~h}$ with $20 \mu \mathrm{L}$ of a ${ }^{3} \mathrm{H}$-leucine solution with a specific activity of $2020 \mathrm{mCi} \cdot \mathrm{mmol}^{-1}$ and a leucine final concentration of $100 \mathrm{nM}$. For each sampling point, 2 controls killed with $50 \mu \mathrm{L}$ of $37 \%$ formol and 4 samples were incubated. Incubations were stopped by addition of $50 \mu \mathrm{L}$ of $37 \%$ formol and samples and controls were kept frozen until protein extraction.

\subsection{Bottom sediment bacterial activity essays}

Flocculent surface bottom sediments were sampled with a peristaltic pump and essayed immediately after sampling, by mixing $100 \mu \mathrm{L}$ of

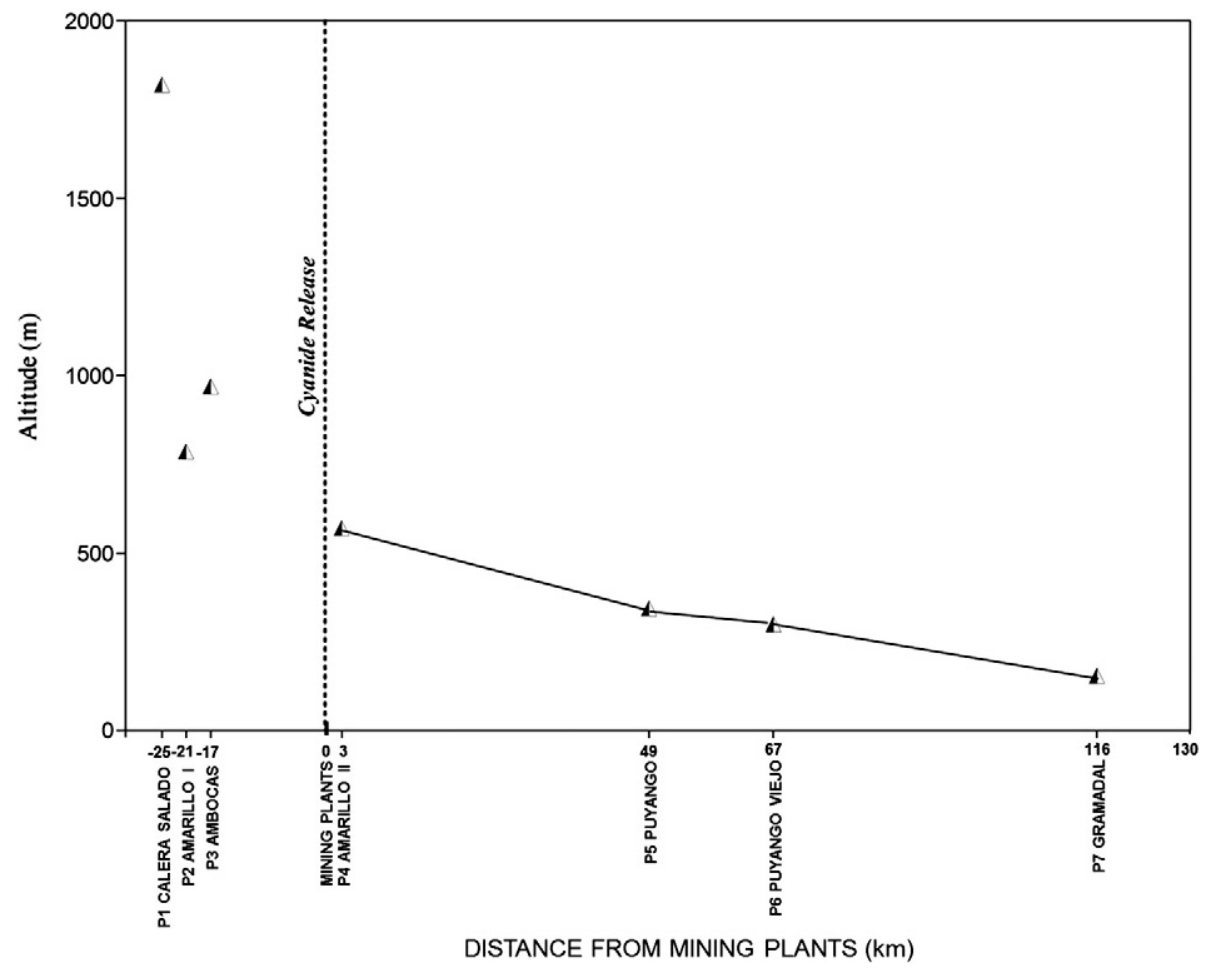

Fig. 2. Altimetric profile of the Puyango river basin. 
sediment suspension with $900 \mu \mathrm{L}$ of river water previously filtered in $0.22 \mu \mathrm{m}$ membrane filters. Essays were started by the addition of $20 \mu \mathrm{L}$ of a ${ }^{3} \mathrm{H}$-leucine solution with a specific activity of $20 \mathrm{mCi}$. $\mathrm{mmol}^{-1}$ and a leucine concentration of $10 \mu \mathrm{mol}$. The other incubation conditions were as described above for water essays.

\subsection{Protein extraction from water and sediment samples}

The bacterial radiolabeled protein extraction was done as described by Miranda et al. (2007) with slight changes in water and sediment sample extraction procedure, as follows.

\subsubsection{Water samples}

After the incubation, $60 \mu \mathrm{L}$ of $100 \%$ Trichloroacetic Acid $( \pm 5 \%$, final concentration) was added to the microcentrifuge tubes for the precipitation of the proteins. The samples were kept in room temperature for $30 \mathrm{~min}$ and then centrifuged (14,000 rpm, $10 \mathrm{~min}$ ). After centrifugation, the supernatant was aspirated carefully. Then $1 \mathrm{~mL}$ 5\% TCA was added to the pellet, followed by homogenization for $10 \mathrm{~s}$ in a vortex, centrifugation and supernatant removal as above. A last clean-up step consisted of adding $1 \mathrm{~mL}$ ice-cold $80 \%$ ethanol, homogenization and centrifugation as above. The supernatant was aspirated and $1 \mathrm{~mL}$ of a scintillation cocktail was added to the samples. After 2 days in the dark, the samples were radioassayed by liquid scintillation counting (Perkin Elmer Tricarb 2800). Dpm data, corrected for quenching, were used to calculate bacterial carbon production $\left(\mu \mathrm{gC} \cdot \mathrm{L}^{-1} \cdot \mathrm{h}^{-1}\right)$.

\subsubsection{Sediment samples}

After the end of incubation samples were sonicated in an ultrasonic bath for $10 \mathrm{~min}$ to detach bacterial cells. After sonication, the samples were centrifuged ( $2500 \mathrm{rpm}, 15 \mathrm{~min})$. The supernatant $(900 \mu \mathrm{L})$ was recovered, transferred to new tubes and $60 \mu \mathrm{L}$ of $100 \%$ Trichloroacetic Acid ( $\pm 5 \%$, final concentration) was added. The samples were kept in room temperature for $30 \mathrm{~min}$ and then centrifuged (14,000 rpm, $10 \mathrm{~min}$ ). After centrifugation, the supernatant was aspirated carefully. Then $1 \mathrm{~mL}$ \% TCA was added to the pellet, followed by homogenization for $10 \mathrm{~s}$ in a vortex, centrifugation and supernatant removal as above. A last clean up step consisted of adding $1 \mathrm{~mL}$ ice-cold $80 \%$ ethanol, homogenization and centrifugation. The supernatant was aspirated and $1 \mathrm{~mL}$ of a scintillation cocktail was added to the samples. After 2 days in the dark, the samples were radioassayed by liquid scintillation counting (Perkin Elmer Tricarb 2800). Dpm data, corrected for quenching, were used to calculate bacterial carbon production $\left(\mu \mathrm{gC} \cdot \mathrm{mg}\right.$ wet weight $\left.\cdot \mathrm{h}^{-1}\right)$.

The relative standard error in the analysis of 4 water or sediment aliquots was respectively $<20$ and $<30 \%$ of the average.

\subsection{Methylmercury production essays in sediments}

$\mathrm{Hg}$ methylation potentials were measured by means of a simplified radiochemical technique consisting of in-situ sample incubation with low amounts of ${ }^{203} \mathrm{Hg}^{2+}$ and extraction of formed $\mathrm{Me}^{203} \mathrm{Hg}$ in toluene and quantification by liquid scintillation counting (Guimarães et al., 1995). Fresh sediment samples, equivalent to $0.5 \mathrm{~g}$ dry weight were incubated in the dark with $30 \mathrm{~mL}$ of river water, in acid-washed Teflon ${ }^{\circledR}$ screw-capped $40 \mathrm{~mL}$ tubes. All incubations started in the field within a few hours after sampling. Duplicates and an acidified control, with $1 \mathrm{~mL}$ of $4 \mathrm{~N} \mathrm{HCl}$, received ${ }^{203} \mathrm{Hg}$, added as ${ }^{203} \mathrm{HgCl}_{2}$, obtained from EckertZiegler, USA, and corresponding to $24 \mathrm{ng} \mathrm{Hg} \cdot \mathrm{g}$ sample dry weight ${ }^{-1}$. The ${ }^{203} \mathrm{Hg}$ stock solution was prepared in deionized water and kept at near $0{ }^{\circ} \mathrm{C}$. Prior to each incubation series its activity was measured on a portable liquid scintillation detector (Triathler Hidex, model 425004) and the added volumes of the ${ }^{203} \mathrm{Hg}$ solution were corrected, if necessary, to keep addition levels at $3500 \mathrm{dpm}$. After $24 \mathrm{~h}$ of incubation, $\mathrm{Hg}$ methylation was stopped by addition of $1 \mathrm{~mL}$ of $4 \mathrm{~N} \mathrm{HCl}$ and samples were frozen until MeHg extraction, performed within 15 days after incubations. $\mathrm{Me}^{203} \mathrm{Hg}$ was leached with $4 \mathrm{~mL}$ of $3 \mathrm{M} \mathrm{NaBr}$ in $11 \% \mathrm{H}_{2} \mathrm{SO}_{4}$ and $1 \mathrm{~mL}$ of $0.5 \mathrm{M} \mathrm{CuSO}_{4}$ : after five minutes of shaking, the samples were centrifuged and the supernatant $(\sim 25 \mathrm{ml})$ was transferred to $60 \mathrm{~mL}$ glass separatory funnels and shaken for $15 \mathrm{~min}$ with $10 \mathrm{~mL}$ of scintillation cocktail $\left(7 \mathrm{~g} \cdot \mathrm{L}^{-1}\right.$ POP $\left(2,5\right.$-diphenyloxazole) and $1 \mathrm{~g} \cdot \mathrm{L}^{-1}$ POPOP [1,4-bis-2-(5-phenyloxazolyl)-benzene] in $1 \mathrm{~L}$ of toluene). The aqueous phase was discarded and the overlying toluene layer transferred to glass tubes for centrifugation at $3000 \mathrm{rpm}$ for $5 \mathrm{~min}$. The clean toluene was shaken in a vial with $0.5 \mathrm{~g}$ of anhydrous $\mathrm{Na}_{2} \mathrm{SO}_{4}$ to remove traces of water containing inorganic ${ }^{203} \mathrm{Hg}$ and transferred to clean scintillation vials for measurement on a Perkin Elmer Tricarb 2800 liquid scintillation detector. Dpm data, corrected for decay, extraction efficiency and quenching were used to calculate $\mathrm{Me}^{203} \mathrm{Hg}$ as a percentage of total added ${ }^{203} \mathrm{Hg}^{2+}$. The relative standard error for measurements on triplicate samples was $\sim 20 \%$.

\section{Results}

As expected, free cyanide was not detectable $\left(<1 \mu \mathrm{g} \cdot \mathrm{L}^{-1}\right)$ in unfiltered water from the three upstream stations and reached $280 \mu \mathrm{g} \cdot \mathrm{L}^{-1}$ in the most impacted station situated $2.5 \mathrm{~km}$ downstream the last cyanidation plant (Fig. 4). Despite the strong declivity of the river basin, as illustrated in Fig. 2, and hence the high turbulence of the river, free cyanide is still at $48 \mu \mathrm{g} \cdot \mathrm{L}^{-1}$ at station 6 , $\sim 80 \mathrm{~km}$ downstream the source, and becomes undetectable only after further $35 \mathrm{~km}$, indicating that the high river turbulence was not enough to oxidize all free cyanide.

At stations 4, 5 and 6, in addition to unfiltered water, free cyanide was also measured in samples filtered through $0.2 \mu \mathrm{m}$ membrane filters and in the three locations $50 \%$ of free cyanide in unfiltered water was in the dissolved phase, therefore readily bioavailable. Our data suggests that during the dry season, when dilution of mining effluents is reduced and mining activity increased, cyanide in water is far above suggested limits for approximately $100 \mathrm{~km}$ downstream the mining areas. Environment Canada (1995) suggests a $24 \mathrm{~h}$ maximum of $3.5 \mu \mathrm{g} \cdot \mathrm{L}^{-1}$ free cyanide and the United States Environmental Protection Agency (1988) a limit of $5.2 \mu \mathrm{g} \cdot \mathrm{L}^{-1}$ total cyanide. If the Puyango river water $2.5 \mathrm{~km}$ downstream the last cyanidation plant was considered as a mining effluent, its cyanide concentration would represent $14 \%$ of the upper limit set for this compound in the current Canadian metal mining effluent regulations (Minister of Justice, Canada, 2002). Our results are comparable to those reported by Tarras-Wahlberg et al. (2001) in the same river basin. The latter also measured cyanide during the raining season, finding lower concentrations but still often above the limits at $60 \mathrm{~km}$ downstream. In our data, a marked decrease in free cyanide is found between stations 6 and 7, from 48 to $2 \mu \mathrm{g} \cdot \mathrm{L}^{-1}$. These stations are in the coastal plain and the longer river water transit time, combined with warmer temperatures, probably favors cyanide decomposition, due to degradation by bacteria and photochemical processes. Total cyanide was not measured in this work and the method we used is unable to recover cyanide that is complexed with metals, including $\mathrm{Hg}$, or other compounds, so that total cyanide in the Puyango river is certainly well above the figures presented here.

Bacterial activity in water along the Puyango river basin shows contrasting patterns when expressed on sample volume basis (Fig. 5 A) or sample amount of suspended particles (Fig. 5 B).

When expressed on a volume basis, the data suggest an increase in activity in the stations downstream the mining area, but this is misleading as most bacteria in water are attached to organic or inorganic particles and the activity per cell is much higher in attached than in free bacteria (Haglund et al., 2002). Consequently, the graph A expresses the huge increase in suspended sediment load and urban waste introduced in the river just upstream station 4, as seen in Fig. 3, rather than a variation in activity per bacterial biomass unit, a parameter that was unfortunately not measured in this study. In 


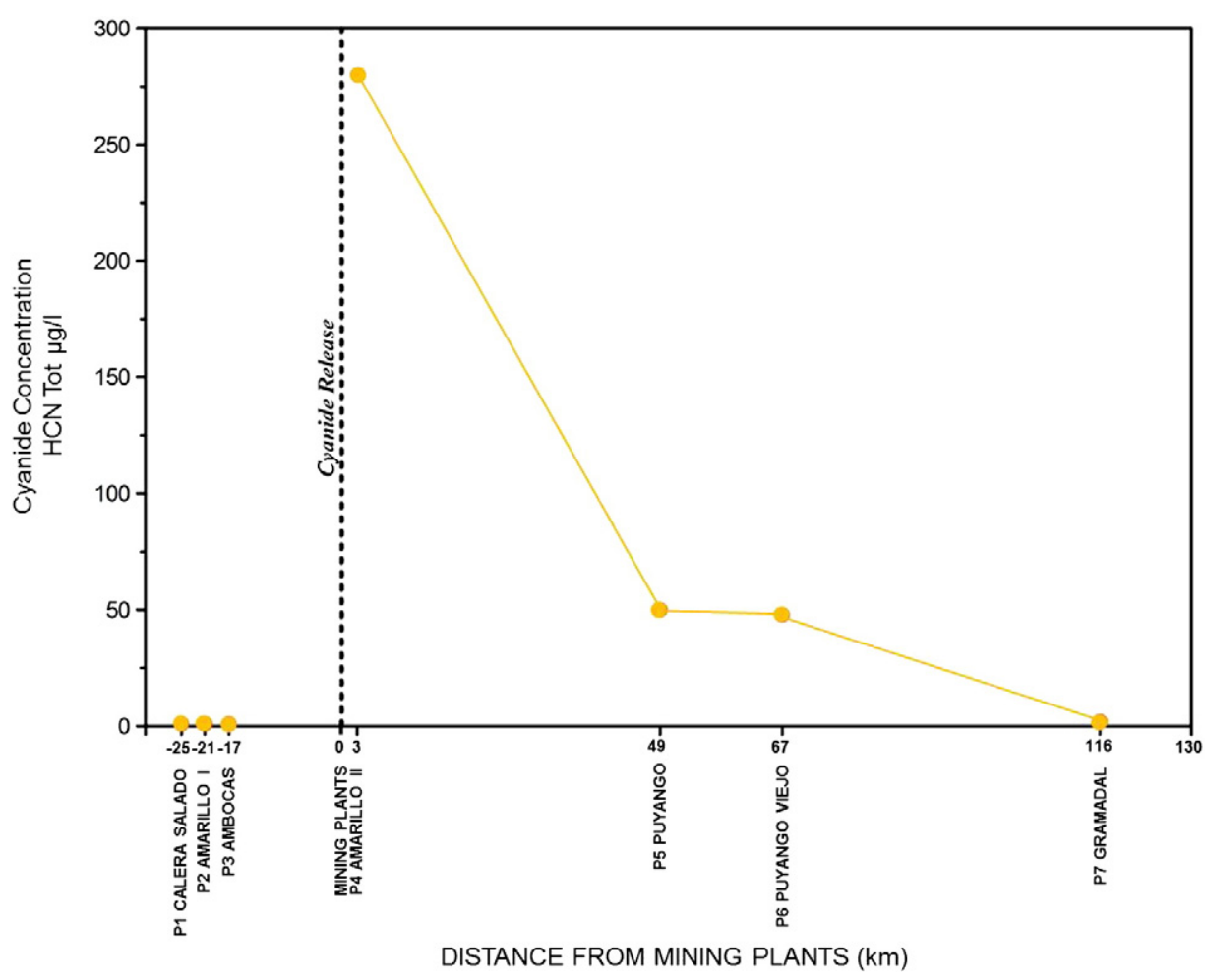

Fig. 4. Total cyanide $\left(\mu \mathrm{g} \cdot \mathrm{L}^{-1}\right)$ in unfiltered water of the Puyango river, measured by in-situ spectrophotometry.

contrast, the graph B, describing activity expressed on basis of the amount of suspended particles, shows a steep decrease in activity in stations downstream the mining area, consistent with the intense point sources of toxic mining waste, especially cyanide. As we did not measure the suspended particles loads in this study, the data in graph B were calculated using the data from a 2004 sampling campaign done during the same period of the hydrological cycle, i.e. the dry season.

$\mathrm{Hg}$ methylation potentials and bacterial activity in sediments vary in the same fashion from station to station, with net methylation potentials of up to $22 \%$ in reference stations, falling to $<0.2 \%$ in the two first stations downstream the processing plants, and reaching $19 \%$ in the most downstream station (Fig. 6).

Bacterial production followed the same pattern, though it remained detectable in stations 4 and 5 , where net methylation was undetectable. $\mathrm{Hg}$ methylation potentials and bacterial production in sediments presented a significant positive correlation $\left(R^{2}=0.68, p<0.022\right.$, Fig. 7).

Downstream the processing plant area, the graphs for bacterial activity and net methylation in sediments are almost a mirror image of the one for cyanide in water, that in turn has similarities with the ones observed in the same season for metals in suspended solids or bottom sediments by Tarras-Wahlberg et al. (2001) and Betancourt et al. (2005). The similarity is due to their common source and to the probable formation of cyanide/metal complexes. Cyanide is a strong metal ligand, which explains its use in the mining industry. However, released together, cyanide and metals drift downstream where cyanide will eventually decompose and release the metals.

The very similar longitudinal profiles of net $\mathrm{Hg}$ methylation and bacterial activity in sediments advocates for a microbiological $\mathrm{Hg}$ methylation process. The methylation potentials measured here in the upper basin stations are higher than found in all previous measurements in sediments from different aquatic systems in Brazil and Bolivia (Guimarães et al., 2000) however the latter did not include temperate humid systems such as the ones in the upper Puyango basin.

\section{Discussion}

We used two radiotracer techniques and a conventional field spectrophotometric one to simultaneously measure free cyanide, bacterial activity in water and sediment and net mercury methylation in sediments along a $140 \mathrm{~km}$ stretch of the Puyango river basin. Previous work by our team (Betancourt et al., 2005) and other researchers has shown the significant impact of mining on this river basin, due to inputs of cyanide and of high loads of suspended material with high concentrations of metals such as $\mathrm{Hg}, \mathrm{Cd}, \mathrm{Pb}, \mathrm{Cu}, \mathrm{Mn}$ and $\mathrm{Zn}$. The apparent paradox observed by Roulet et al. (2006) of high total $\mathrm{Hg}$ concentrations but very low $\mathrm{MeHg}$ concentrations in stations downstream the mining area lead us to investigate the impact of mining effluents on bacterial activity and microbial mercury methylation on the same river stretch. Our data show the suppression or drastic decrease of bacterial activity and mercury methylation in water and sediment downstream the mining area, where free dissolved cyanide concentrations are highest, and recovery of these parameters in the stations at greater distances from the pollution sources, where cyanide is lower or undetectable. This suggests that cyanide toxicity for bacteria reduced their activity and consequently microbial mercury methylation. However, though the reduced bacterial activity alone could explain the reduction in mercury methylation, the latter can also be reduced by factors other than cyanide toxicity for microbes. The formation of both cyanide- $\mathrm{Hg}$ complexes and of sulfur-Hg complexes reduces $\mathrm{Hg}$ (II) availability for methylation. Accordingly, Tarras-Wahlberg et al. (2001) found that though sediments were enriched in mercury throughout the Puyango middle and lower basin, the proportions of reactive $\mathrm{Hg}$ were very low. Roulet et al. (2006) showed that $\mathrm{Hg}$ and $\mathrm{S}$ correlated positively in sediments and suspended particles downstream the mining areas of the same river stretch as herein, both in the dry and wet seasons (Fig. 8). Another factor that may contribute to a low availability of $\mathrm{Hg}$ downstream gold mining fields is the formation of micro-droplets of metallic $\mathrm{Hg}$ onto hydrous iron oxides and clay minerals (Meech et al., 1998). In a previous unpublished work in the region we found less total $\mathrm{Hg}$ in the piscivorous fish 


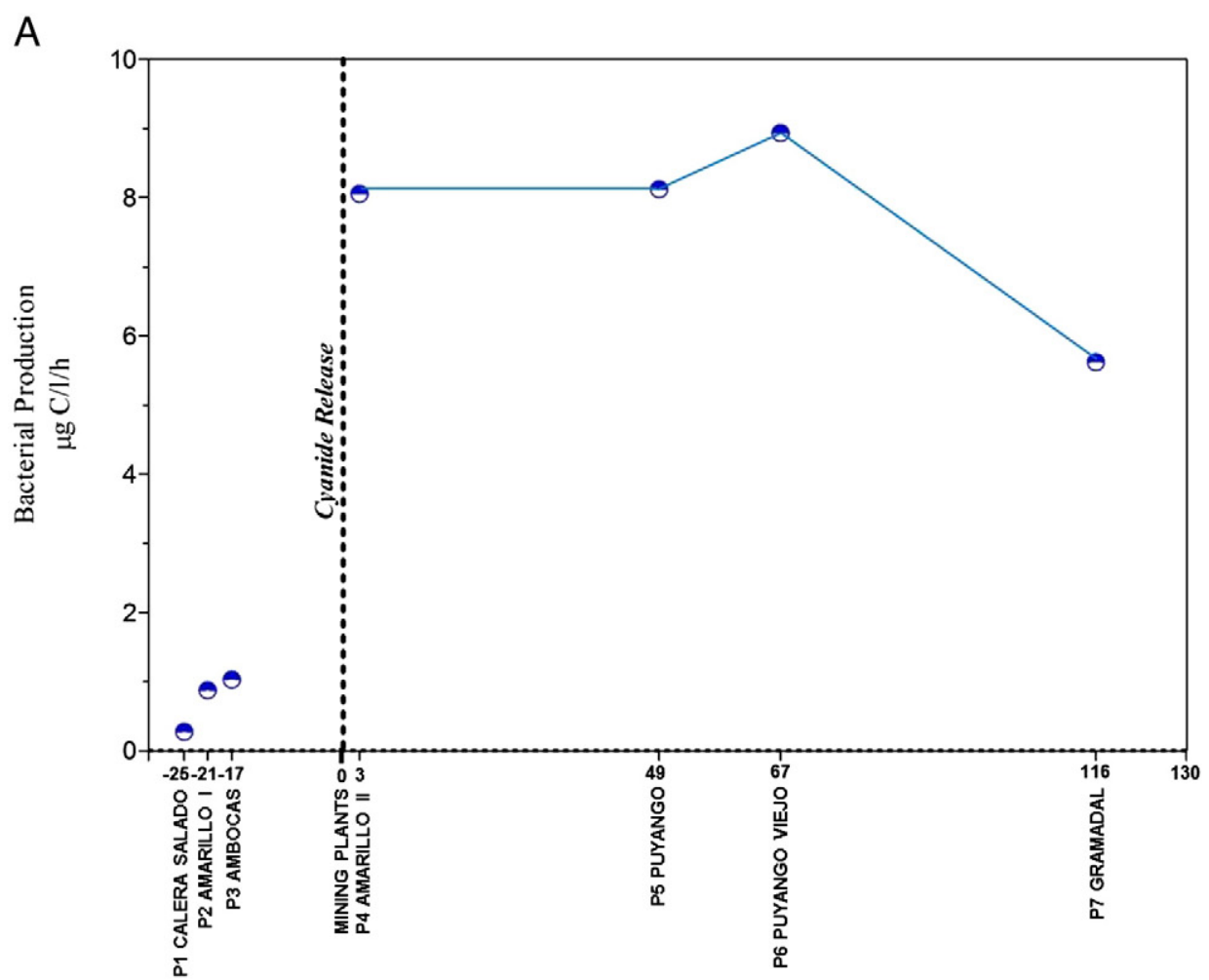

DISTANCE FROM MINING PLANTS $(\mathrm{km})$

B

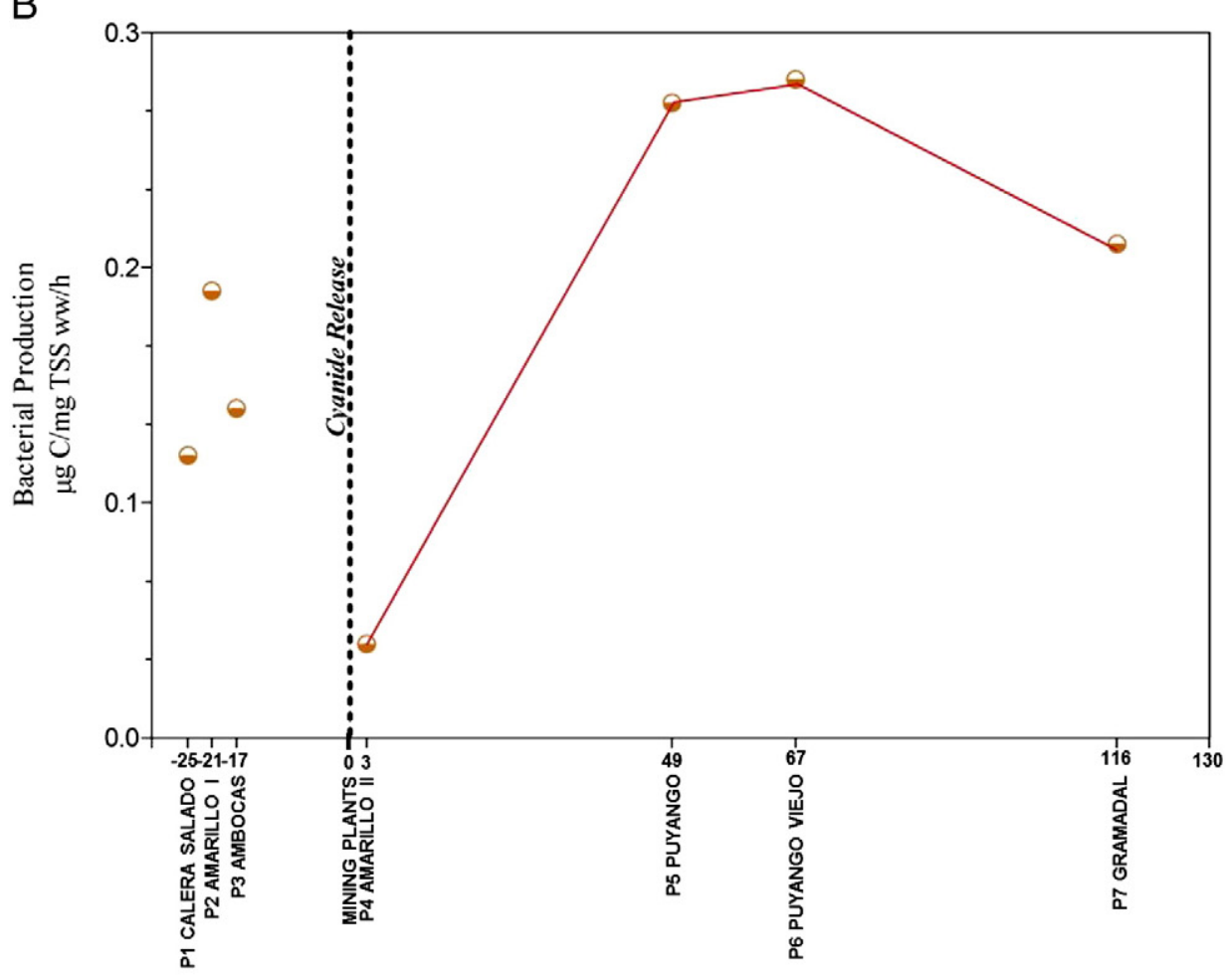

DISTANCE FROM MINING PLANTS $(\mathrm{km})$

Fig. 5. Bacterial activity in water of the Puyango river expressed on a volume (graph $\mathrm{A}, \mu \mathrm{gC} \cdot \mathrm{L}^{-1} \cdot \mathrm{h}^{-1}$ ) and SPM mass $\left(\mathrm{graph} \mathrm{B}, \mu \mathrm{gC} \cdot \mathrm{mg} \mathrm{ww}{ }^{-1} \cdot \mathrm{h}^{-1}\right)$ basis.

Brycon atrocaudatus in the middle Puyango basin $\left(0.8 \mu \mathrm{g} \cdot \mathrm{g}^{-1}\right.$ wet weight, $\mathrm{N}=8)$ than in the lower basin $\left(1.5 \mu \mathrm{g} \cdot \mathrm{g}^{-1}\right.$ wet weight, $\mathrm{N}=14$ ), (Barriga $\mathrm{R}$ et al. in prep.). Unfortunately, no data are available so far on the speciation of $\mathrm{Hg}$ in fish from the Puyango river, including $\mathrm{MeHg}$ or other organic and inorganic $\mathrm{Hg}$ compounds, in particular
cyanide-Hg complexes, that may be directly bioaccumulated (Velásquez-López et al., 2011).

In the local ore, gold is indeed associated to S-rich minerals, but the presence of carbonate rocks and the low residence time of mining tailings on the river banks do not favor the production of acid mine 


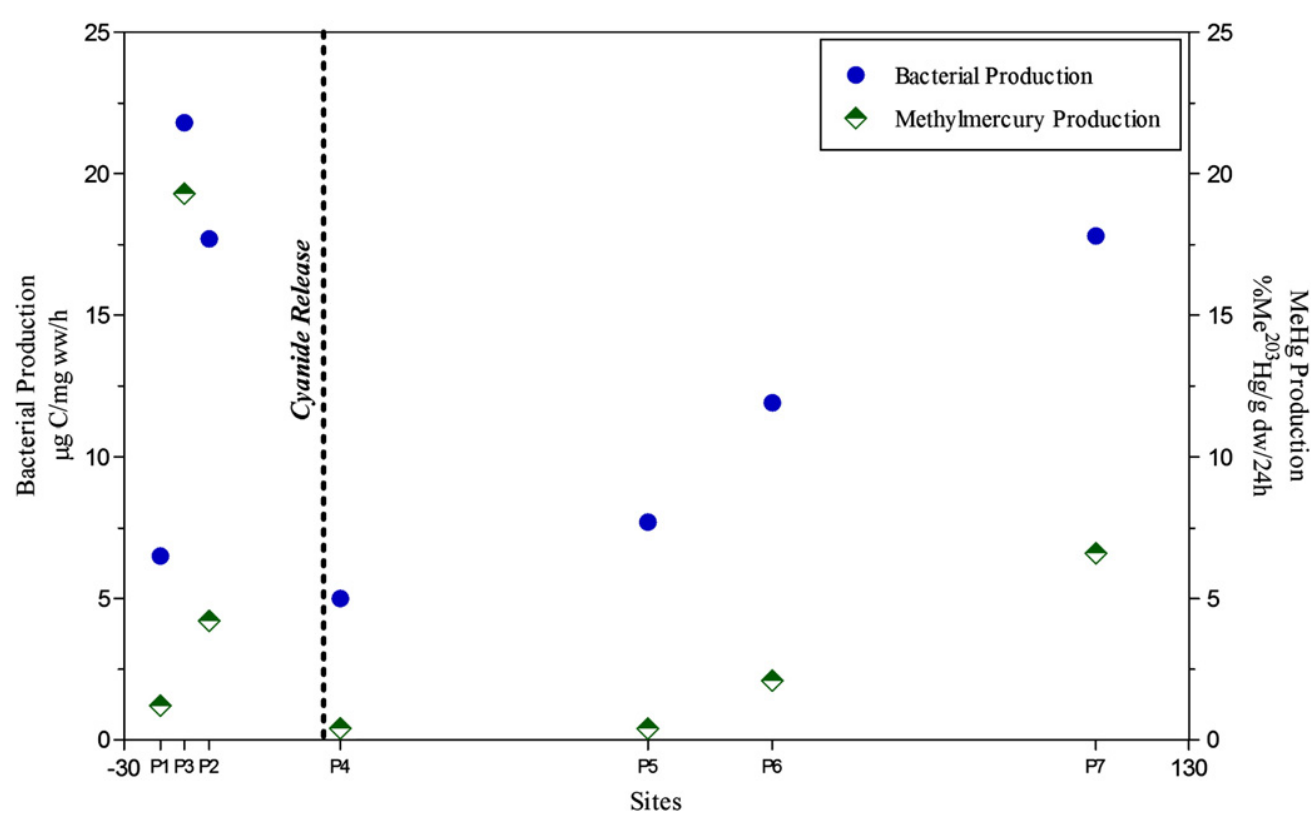

Fig. 6. $\mathrm{Hg}$ methylation potentials (\% of total ${ }^{203} \mathrm{Hg} \cdot \mathrm{g}$ dry weight ${ }^{-1} \cdot$ day $^{-1}$ ) and bacterial production ( $\mu \mathrm{gC} \cdot \mathrm{mg} \mathrm{wet}$ weight $^{-1} \cdot \mathrm{h}^{-1}$ ) in bottom sediments along the Puyango river basin.

drainage, and previous work in the region by Roulet et al. (2006) showed that water $\mathrm{pH}$ was lower (6.3-7.0) in reference upstream points than 2.5 to $110 \mathrm{~km}$ downstream the mines (6.6-8.1). In the absence of prevalent acid mine drainage, cyanide alone could explain the eradication of the aquatic biota in stations downstream the mining area but the impact of increased metal concentrations and of the direct dumping of nearly a million $t$ of tailings per annum in the river certainly plays a relevant role. In fact, in gold mining areas where amalgamation or processes other than cyanidation are used for gold recovery, the finding of significant $\mathrm{MeHg}$ concentrations and $\mathrm{MeHg} / \mathrm{total} \mathrm{Hg}$ ratios downstream the mines is rather the rule than the exception, as reported by Gray et al. (2002) in Suriname, Gray et al. (2004) in Almaden, Spain, Stamenkovic et al. (2004) in Nevada, USA, Johnson et al. (2009) in California, USA, and Boudou et al. (2005) in French Guyana, to cite a few. Even in active or historical mining sites where sulfide concentrations are higher, reducing $\mathrm{Hg}$ reactivity, enhanced methylation may be found further downstream (Domagalski, 2001).

In our study site, as put by Tarras-Wahlberg et al. (2001) "Elucidating the relative severity of impact of the mining related contaminants is made difficult by the fact that cyanide, mercury and metal rich tailings are present together in the affected rivers". However,

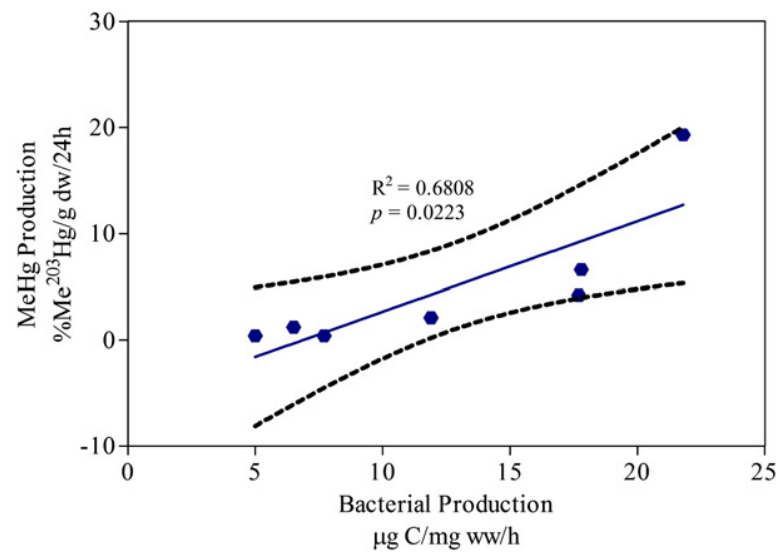

Fig. 7. Hg methylation potentials plotted against bacterial production, sediments of the Puyango river basin. the same authors measured cyanide and metals in two different branches of the Puyango basin with similar metal concentrations but with cyanide concentrations differing by one to two orders of magnitude and suggest that cyanide rather than metals would explain the eradication of biota on long river stretches. Our data showing the strong inhibition of bacterial activity downstream the mining area gives additional support to this hypothesis.

\section{Conclusion}

The inhibition of MeHg formation on a long river stretch downstream a gold mining area is a peculiar finding that reflects the interplay of ecosystem characteristics and human activities, with implications for health. It may explain, together with the low fish intake, the low total mercury in human hair in the basin (mean $1.17 \mu \mathrm{g} \cdot \mathrm{g}^{-1}$ ). Though

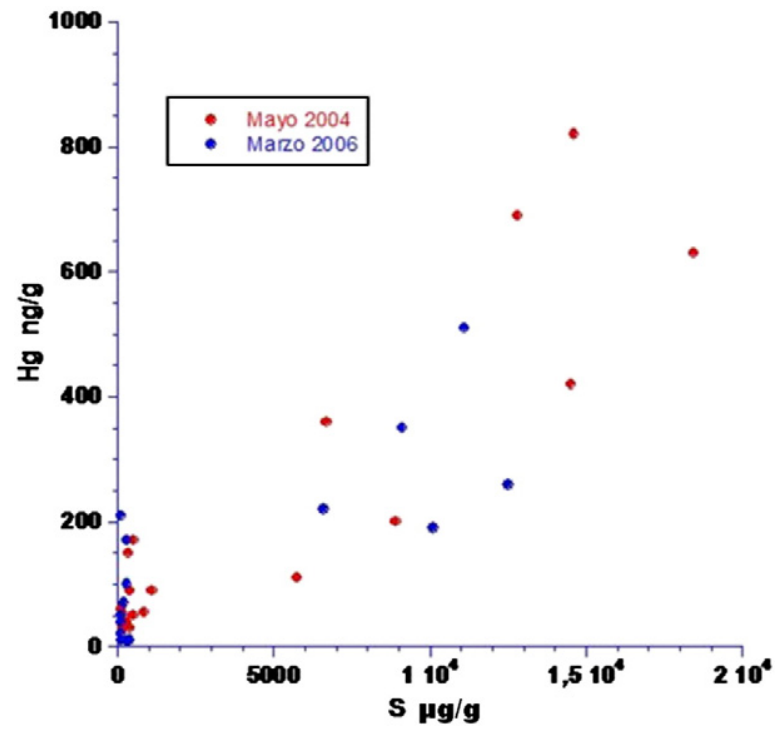

Fig. 8. Total Hg and Sulfur in suspended particles along the Puyango river Basin in the dry and wet seasons. From Roulet et al. (2006). 
toxic by itself, cyanide ironically seems to reduce mercury toxicity, by reducing $\mathrm{MeHg}$ formation and consequently mercury bioavailability to the local population.

However, we showed here that when reaching the coastal plain, the Puyango river shows no detectable cyanide in water and that mercury methylation in its sediments returns to levels comparable to the ones in pristine stations. In contrast with pristine stations, the coastal plain sediments and suspended particles are rich in mercury, and further downstream, intensive shrimp farming is the main economic activity, in a potential conflict between two activities of comparable economic importance to Ecuador.

\section{Acknowledgments}

This study was financially supported by the International Development Research Center (IDRC) of Canada (Grant 04291/98-0232), and CAPES (Coordenaçao de Aperfeiçoamento de Pessoal de Ensino Superior) and CNPq (Conselho Nacional de Desenvolvimento Cientifico e Tecnologico) from Brazil. The support of the riverine population of the study area was appreciated, as well as the suggestions on the manuscript by Marcelo Veiga, UBC (Canada).

This work is dedicated in the memory of our colleague and very close friend Marc Roulet, (1967-2006), a distinguished biogeochemist at Institut de Recherche pour le Developpement, La Paz, Bolivia, who enthusiastically participated in this project.

\section{References}

Astudillo C. The sweat of the sun: history of gold mining, Ediciones La Tierra; 2007. 190 pp. (In Spanish).

Betancourt O, Narvaez A, Roulet M. Small-scale gold mining in the Puyango River Basin, Southern Ecuador: a study of environmental impacts and human exposures. Ecohealth 2005;2:323-32.

Boudou A, Maury-Brachet R, Coquery M, Durrieu G, Cossa D. Synergic effect of gold mining and damming on mercury contamination in fish. Environ Sci Technol 2005;39:2448-54

Domagalski J. Mercury and methylmercury in water and sediment of the Sacramento River Basin, California. Appl Geoch 2001:1677-91.

Environment Canada. Interim sediment quality guidelines. Ecosystem Conservation Directorate. Ottawa: Evaluation and Interpretation Branch, Guidelines. Division; 1995. p. 9.

Gray JE, Labson VF, Weaver JN, Krabbenhoft DP. Mercury and methylmercury contamination related to artisanal gold mining, Suriname. Geophys Res Lett 2002;29:2105.
Gray JE, Hines ME, Higueras PL, Adatto I, Lasorsa BK. Mercury speciation and microbial transformations in mine wastes, stream sediments, and surface waters at the Almaden Mining District, Spain. Environ Sci Technol 2004;38:4285-92.

Guimarães JRD, Malm O, Pfeiffer WC. A simplified radiochemical technique for measurement of net mercury methylation rates in aquatic systems near goldmining areas, Amazon, Brazil. Sci Total Environ 1995;175:151-62.

Guimarães JRD, Meili M, Hylander LD, Castro e Silva E, Roulet M, Mauro JBN, et al. Net mercury methylation in five tropical flood plain regions of Brazil: high in the root zone of floating macrophyte mats but low in surface sediments and flooded soils. Sci Total Environ 2000;261:99-107.

Haglund AL, Törnblom E, Boström B, Tranvik L. Large differences in the fraction of active bacteria in plankton, sediments, and biofilm. Microb Ecol 2002;43:232-41.

Johnson BE, Esser BK, Whyte DC, Ganguli PM, Austin CM, Hunt JR. Mercury accumulation and attenuation at a rapidly forming delta with a point source of mining waste. Sci Total Environ 2009;407:5056-70.

Kirchman DL, Knees E, Hodson RE. Leucine incorporation and its potential as a measure of protein synthesis by bacteria in natural aquatic systems. Appl Environ Microbiol 1985;49:599-607.

Meech JA, Veiga MM, Tromans D. Reactivity of mercury from gold mining activities in darkwater ecosystems. Ambio 1998;27:92-8.

Minister of Justice. Canada, metal mining effluent regulations, SOR/2002-222. Available at http://laws-lois.justice.gc.ca.

Miranda MR, Guimarães JRD, Coelho-Souza AS. $\left[{ }^{3} \mathrm{H}\right]$ leucine incorporation method as a tool to measure secondary production by periphytic bacteria associated to the roots of floating aquatic macrophytes. J Microb Meth 2007;71(1):23-31.

PRODEMINCA. Evaluation of impacts in the mining district of Zaruma-Portovelo and the Puyango river basin. Proyecto Desarrollo Minero y Control Ambiental, Prodeminca. Quito: Swedish Environmental Systems. Ministerio de Energia y Minas del Ecuador; 1998. 212 pp. (In Spanish).

Roulet M, Cueva E, Sandoval J, Iñiguez V, Betancourt O. Gold mining in the Andes (Ecuador) can lower MeHg in sediments. Coloquio Internacional sobre la Biogeoquímica de los Metales en el Medio Ambiente y su Impacto en la Salud de las Poblaciones Humanas, IRD/UMSA, La Paz, Bolivia; 2006. Nov. (In Spanish).

Stamenkovic J, Gustin MS, Marvin-DiPasquale MC, Thomas BA, Agee JL. Distribution of total and methyl mercury in sediments along Steamboat Creek (Nevada, USA). Sci Total Environ 2004;322:167-77.

Tarras-Wahlberg NH, Flachier A, Lane SN, Sangfors O. Environmental impacts and metal exposure of aquatic ecosystems in rivers contaminated by small scale gold mining: the Puyango River basin, southern Ecuador. Sci Total Environ 2001;278: 239-61.

United States Environmental Protection Agency. Ore mining and dressing point source category effluent limitations guidelines, 40 CFR 440; 1988.

Veiga M.M. Personnal communication, May 2011.

Velasquez-Lopez PC, Veiga MM, Hall K. Mercury balance in amalgamation in artisanal and small-scale gold mining: identifying strategies for reducing environmental pollution in Portovelo-Zaruma, Ecuador. J Clean Prod 2010;18:226-32.

Velásquez-López PC, Veiga MM, Klein B, Shandro JA, Hall K. Cyanidation of mercuryrich tailings in artisanal and small-scale gold mining: identifying strategies to manage environmental risks in Southern Ecuador. J Clean Prod 2011;19:1125-33. 